\title{
Luteimonas aquatica sp. nov., isolated from fresh water from Southern Taiwan
}

\author{
Jui-Hsing Chou, ${ }^{1}$ Nian-Tsz Cho, ${ }^{2}$ A. B. Arun, ${ }^{1}$ Chiu-Chung Young ${ }^{1}$ \\ and Wen-Ming Chen ${ }^{2}$ \\ ${ }^{1}$ Department of Soil and Environmental Sciences, College of Agriculture and Natural Resources, \\ National Chung Hsing University, Taichung, Taiwan, ROC \\ ${ }^{2}$ Laboratory of Microbiology, Department of Seafood Science, National Kaohsiung Marine \\ University, 142 Hai-Chuan Road, Nan-Tzu, Kaohsiung City 811, Taiwan, ROC
}

Correspondence Wen-Ming Chen p62365@ms28.hinet.net

\begin{abstract}
A yellow-pigmented bacterial strain, designated RIB1 $-20^{\top}$, isolated from fresh water was investigated by means of a polyphasic taxonomic approach. The cells were Gram-negative, rodshaped and non-spore-forming. Phylogenetic analyses with the 16S rRNA gene sequence showed that the strain formed a monophyletic branch towards the periphery of the evolutionary radiation occupied by the genus Luteimonas, its two closest neighbours being Luteimonas composti CC-YY $255^{\top}$ (96.1\% sequence similarity) and Luteimonas mephitis B1953/27.1 ${ }^{\top}$ (95.8\%). Strain RIB1-20 $0^{\top}$ was clearly distinguished from both of those type strains using phylogenetic analysis, DNA-DNA hybridization, fatty acid composition data and a range of physiological and biochemical characteristics. It is evident from the genotypic and phenotypic data that strain RIB1-20 $0^{\top}$ represents a novel species of the genus Luteimonas, for which the name Luteimonas aquatica sp. nov. is proposed. The type strain is RIB1-20 ${ }^{\top}$ (=BCRC $17731^{\top}$ $=$ LMG $24212^{\top}$ ).
\end{abstract}

During the characterization of micro-organisms in water samples collected from a freshwater spring located in Kaohsiung County, Taiwan, a yellow-coloured strain, designated RIB1-20 ${ }^{\mathrm{T}}$, was isolated and maintained on R2A agar (BD Difco) plates after incubation at $25{ }^{\circ} \mathrm{C}$ for 3 days. Subcultivation was performed on R2A agar at $25{ }^{\circ} \mathrm{C}$ for between 48 and $72 \mathrm{~h}$. On this medium, strain RIBI- $20^{\mathrm{T}}$ was able to grow at $15-37{ }^{\circ} \mathrm{C}$, but not at 10 or $40{ }^{\circ} \mathrm{C}$. The organism was able to grow on $\mathrm{R} 2 \mathrm{~A}$, nutrient agar (BD Difco) and tryptic soy agar (BD Difco).

Cells were observed with phase-contrast microscopy (DM 2000; Leica) in the lag, exponential and stationary phases of growth to ascertain their morphology. Motility was tested by means of the hanging-drop method. The Gram stain set S kit (BD Difco) and the Ryu non-staining KOH method (Powers, 1995) were used to test the Gram-staining reaction. Accumulation of poly- $\beta$-hydroxybutyrate granules was investigated using light microscopy after staining of the cells with Sudan black. Colony morphology was observed on R2A agar, using a stereoscopic microscope (SMZ 800; Nikon). Details of the morphology are given in the species description.

The GenBank/EMBL/DDBJ accession number for the $16 \mathrm{~S}$ rRNA gene sequence of strain RIB1-20 ${ }^{\top}$ is EF626688.

An expanded neighbour-joining phylogenetic tree, based on 16S rRNA gene sequences, for strain RIB1-20 $0^{\top}$ and related taxa is available as supplementary material with the online version of this paper.
The $\mathrm{pH}$ range for growth was determined by measuring the $\mathrm{OD}_{600}$ of cultures grown on nutrient broth (BD Difco) adjusted to various $\mathrm{pH}$ values $(\mathrm{pH} 4-10$, in increments of $1.0 \mathrm{pH}$ unit), prior to sterilization, using appropriate biological buffers (Chung et al., 1995). To investigate $\mathrm{NaCl}$ tolerance, nutrient broth was prepared according to the formula of the BD Difco medium, while $\mathrm{NaCl}$ concentrations were varied $(0,0.5$ and $1.0-10.0 \%$, w/v, in increments of $1.0 \%)$. Growth under anaerobic conditions was determined after incubating strain RIB $1-20^{\mathrm{T}}$ in an Oxoid AnaeroGen system. Strain RIB $1-20^{\mathrm{T}}$ was examined for a broad range of phenotypic properties. Catalase, oxidase, DNase, arginine dihydrolase, urease and lipase activities and hydrolysis of starch, casein and Tweens 20, 40, 60 and 80 were determined using standard methods (Gerhardt et al., 1994; Lányí, 1987; MacFaddin, 2000). Phenotypic characteristics, biochemical data, carbonsource utilization results (Biolog GN2) and API ZYM and API 20NE (both from bioMérieux) profiles were investigated. For $\mathrm{G}+\mathrm{C}$ content determinations, DNA was prepared and degraded enzymically into nucleosides as described by Mesbah et al. (1989). The nucleoside mixture obtained was then separated by using HPLC. The DNA $\mathrm{G}+\mathrm{C}$ content of strain RIB $1-20^{\mathrm{T}}$ was $70.3 \mathrm{~mol} \%$.

The 16S rRNA gene sequence was analysed as described previously Chen et al. (2001). Analysis of the sequence data was performed by using BioEdit (Hall, 1999) and MEGA, 
version 3.1 (Kumar et al., 2004), after the performance of multiple alignments of the data by CLUSTAL_X (Thompson et al., 1997). A distance matrix method (with distance options according to Kimura's two-parameter model; Kimura, 1983), including clustering using neighbourjoining (Saitou \& Nei, 1987) (Fig. 1 and Supplementary Fig. S1, available in IJSEM Online), and a discrete character-based maximum-parsimony method (Kluge \& Farris, 1969) were used. In each case, bootstrap percentages based on 1000 replications were calculated. The $16 \mathrm{~S}$ rRNA gene sequence of strain RIB1- $20^{\mathrm{T}}$ was a continuous stretch of $1481 \mathrm{bp}$. Sequence-similarity calculations (over $1350 \mathrm{bp}$ ) indicated that strain RIB1 $-20^{\mathrm{T}}$ was most closely related to Luteimonas composti CC-YY255 ${ }^{\mathrm{T}}$ (96.1\% similarity) and Luteimonas mephitis B1953/27.1 ${ }^{\mathrm{T}}$ (95.8\%). Lower levels of sequence similarity $(<94.0 \%)$ were found with respect to representative members of the other genera shown in Fig. 1 and Supplementary Fig. S1.

DNA-DNA hybridization experiments were performed with L. composti CCUG $53595^{\mathrm{T}}$ and L. mephitis DSM $12574^{\mathrm{T}}$ using the method described by Ezaki et al. (1989). The results indicated low levels of relatedness between strain RIB1 $-20^{\mathrm{T}}$ and its closest phylogenetic neighbours, $L$. composti CCUG $53595^{\mathrm{T}}(48 \pm 5 \%)$ and L. mephitis DSM $12574^{\mathrm{T}}(23 \pm 2 \%)$. These values are clearly below the $70 \%$ cut-off point recommended for the assignment of strains to the same genomic species (Wayne et al., 1987).

Fatty acid methyl esters were prepared, separated and identified according to the instructions of the Microbial Identification System (Microbial ID; Sasser, 1990). The fatty acid profile of strain RIB1-20 $0^{\mathrm{T}}$ (Table 1 ) was similar to those given for L. composti and L. mephitis (Young et al., 2007; Finkmann et al., 2000), but there were some significant differences (Table 1).

Sensitivity to antibiotics was tested by spreading cells of strain RIB1 $-20^{\mathrm{T}}$ (density of $0.5 \mathrm{McF}$ arland standard) on Mueller-Hinton agar (BD Difco) plates and adding antibiotic discs (Oxoid) containing the following: ampicillin $(10 \mu \mathrm{g})$, chloramphenicol $(30 \mu \mathrm{g})$, gentamicin
$(10 \mu \mathrm{g})$, kanamycin $(30 \mu \mathrm{g})$, nalidixic acid $(30 \mu \mathrm{g})$, novobiocin $(30 \mu \mathrm{g})$, rifampicin $(5 \mu \mathrm{g})$, penicillin $\mathrm{G}(10 \mu \mathrm{g})$, streptomycin $(10 \mu \mathrm{g})$, sulfamethoxazole $(23.75 \mu \mathrm{g})$ plus trimethoprim $(1.25 \mu \mathrm{g})$ or tetracycline $(30 \mu \mathrm{g})$. The effect of antibiotics on cell growth was assessed after 3 days and susceptibility was scored on the basis of the distance from the edge of the clear zone to the edge of the disc. If the distance was greater than $3 \mathrm{~mm}$ the strain was classified as susceptible, if the distance was between 1 and $3 \mathrm{~mm}$ the strain was classified as moderately susceptible and if the clear zone was less than $1 \mathrm{~mm}$ the strain was considered resistant.

The results of physiological characterization are given in the species description and in Table $2 ;$ L. composti CCUG $53595^{\mathrm{T}}$ and L. mephitis DSM $12574^{\mathrm{T}}$ were tested for comparison.

Strain RIB1-20 $0^{\mathrm{T}}$ was capable of producing acid from various carbohydrates. However, carbon-substrate utilization tests involving organic acids as the substrates produced few positive results. In API 20NE tests, strain RIB1-20 ${ }^{\mathrm{T}}$ showed positive reactions for $\beta$-glucosidase, protease, $\beta$-galactosidase, oxidase and catalase and for assimilation of glucose, mannose, $\mathrm{N}$-acetylglucosamine, maltose and malate; negative results were obtained for nitrate and nitrite reduction, indole production, glucose acidification, arginine dihydrolase and urease and for assimilation of arabinose, mannitol, gluconate, caprate, adipate, citrate and phenyl acetate. With the API ZYM system, strain RIB1-20 ${ }^{\mathrm{T}}$ showed positive reactions for alkaline phosphatase, esterase (C4), esterase lipase (C8), leucine arylamidase, valine arylamidase, cystine arylamidase, acid phosphatase, naphthol-AS-BI-phosphohydrolase and $N$-acetyl- $\beta$-glucosaminidase and produced negative reactions for lipase (C14), trypsin, $\alpha$-chymotrypsin, $\alpha$ galactosidase, $\beta$-glucuronidase, $\alpha$-mannosidase and $\alpha$ fucosidase.

On the basis of these results, we propose that strain RIB1$20^{\mathrm{T}}$ represents a novel species of the genus Luteimonas, for which the name Luteimonas aquatica sp. nov. is proposed.

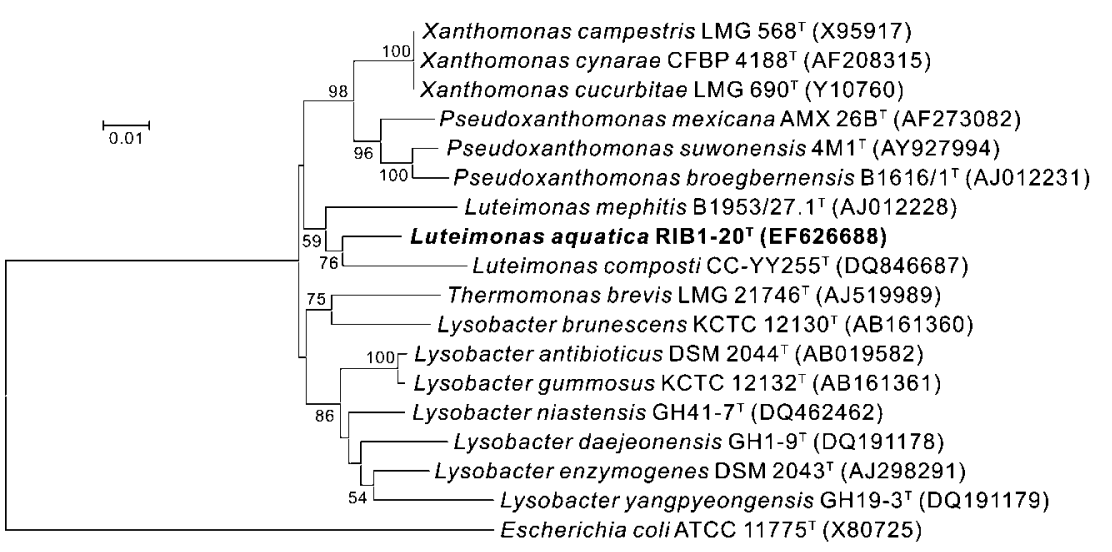

Fig. 1. Phylogenetic tree, based on $16 \mathrm{~S}$ rRNA gene sequences, for strain RIB1-20 ${ }^{\top}$ and related taxa. Distances and clustering with the neighbour-joining method were performed by using the software package MEGA, version 3.1. Accession numbers are shown in parentheses. Bootstrap percentages (based on 1000 replications) are shown at branching points. Bar, 0.01 substitutions per nucleotide position. An extended version of this tree is available as Supplementary Fig. S1. 
Table 1. Fatty acid compositions of strain RIB $1-20^{\top}$ and type strains of Luteimonas species

Values are percentages of total fatty acid content. Data for L. mephitis DSM $12574^{\mathrm{T}}$ and L. composti CCUG $53595^{\mathrm{T}}$ are from Young et al. (2007). Strain RIB $1-20^{\mathrm{T}}$ was cultured on tryptic soy broth agar (BD Difco) at $28{ }^{\circ} \mathrm{C}$ for $48 \mathrm{~h}$, these conditions being similar to those described for L. mephitis DSM $12574^{\mathrm{T}}$ and L. composti CCUG $53595^{\mathrm{T}}$ in Young et al. (2007). -, Not detected; ECL, equivalent chain length.

\begin{tabular}{|c|c|c|c|}
\hline Fatty acid & $\begin{array}{c}\text { Strain } \\
\text { RIB1-20 }\end{array}$ & $\begin{array}{c}\text { L. mephitis } \\
\text { DSM } 12574^{\mathrm{T}}\end{array}$ & $\begin{array}{l}\text { L. composti } \\
\text { CCUG } \\
53595^{\mathrm{T}}\end{array}$ \\
\hline \multicolumn{4}{|c|}{ Saturated straight-chain } \\
\hline $\mathrm{C}_{10: 0}$ & - & 0.1 & - \\
\hline $\mathrm{C}_{14: 0}$ & 0.2 & 0.7 & - \\
\hline $\mathrm{C}_{16: 0}$ & 2.4 & 1.6 & 4.7 \\
\hline$C_{16: 0}$ & 0.1 & - & - \\
\hline \multicolumn{4}{|c|}{ Saturated branched } \\
\hline iso- $\mathrm{C}_{10: 0}$ & - & 0.1 & 0.4 \\
\hline iso- $\mathrm{C}_{11: 0}$ & 4.0 & 5.2 & 6.5 \\
\hline anteiso- $\mathrm{C}_{11: 0}$ & - & 0.2 & 0.3 \\
\hline iso- $\mathrm{C}_{13: 0}$ & 0.2 & 0.5 & - \\
\hline iso- $\mathrm{C}_{14: 0}$ & 0.3 & 1.5 & 1.9 \\
\hline iso- $\mathrm{C}_{15: 0}$ & 25.3 & 47.4 & 25.5 \\
\hline anteiso- $\mathrm{C}_{15: 0}$ & 6.2 & 3 & 2.7 \\
\hline iso- $\mathrm{C}_{16: 0}$ & 4.4 & 5.6 & 13.8 \\
\hline iso- $\mathrm{C}_{17: 0}$ & 21.5 & 5.5 & 5.5 \\
\hline anteiso- $\mathrm{C}_{17: 0}$ & 1.9 & - & - \\
\hline iso- $\mathrm{C}_{18: 0}$ & 0.2 & - & - \\
\hline \multicolumn{4}{|l|}{ Unsaturated } \\
\hline iso- $\mathrm{C}_{15: 1}$ & - & 3 & 1.9 \\
\hline iso- $\mathrm{C}_{17: 1} \omega 9 c$ & 22.3 & 18.7 & 25.5 \\
\hline \multicolumn{4}{|l|}{ Hydroxy } \\
\hline iso- $\mathrm{C}_{11: 0} 3-\mathrm{OH}$ & 6.7 & 5.3 & 5.5 \\
\hline iso- $\mathrm{C}_{12: 0} 3-\mathrm{OH}$ & 0.1 & - & - \\
\hline iso- $\mathrm{C}_{17: 0} 3-\mathrm{OH}$ & 0.6 & - & - \\
\hline \multicolumn{4}{|c|}{ Summed features ${ }^{\star}$} \\
\hline 3 & 1.4 & 0.9 & 5.5 \\
\hline 4 & 0.4 & - & - \\
\hline \multicolumn{4}{|l|}{ Unknown } \\
\hline ECL 11.799 & 1.5 & - & - \\
\hline ECL 14.263 & 0.1 & - & - \\
\hline \multicolumn{4}{|c|}{ Cyclopropane acid } \\
\hline $\mathrm{C}_{17: 0}$ cyclo & - & 0.2 & - \\
\hline
\end{tabular}

* Summed features are groups of two or three fatty acids that cannot be separated by GLC with the MIDI system. Summed feature 3 contained $\mathrm{C}_{16: 1} \omega 7 c$ and/or iso- $\mathrm{C}_{15: 0}$ 2-OH. Summed feature 4 contained anteiso- $\mathrm{C}_{17: 1} \mathrm{~B}$ and/or iso- $\mathrm{C}_{17: 1} \mathrm{I}$.

\section{Description of Luteimonas aquatica sp. nov.}

Luteimonas aquatica (a.qua'ti.ca. L. fem. adj. aquatica found in water, aquatic).

Cells are aerobic, Gram-negative, non-spore-forming, nonmotile and rod-shaped. Poly- $\beta$-hydroxybutyrate granules
Table 2. Phenotypic characteristics that separate strain RIB $1-20^{\top}$ from L. composti CCUG $53595^{\top}$ and L. mephitis DSM $12574^{\top}$

All of the data shown were obtained in this study, except for the $\mathrm{G}+\mathrm{C}$ content of L. mephitis DSM $12574^{\mathrm{T}}$, which was taken from Lipski \& Stackebrandt (2005). All three strains tested positive for the following: utilization of glycogen, Tweens 40 and $80, N$-acetyl-D-glucosamine, Dfructose, pyruvic acid methyl ester, bromosuccinic acid, L-alanyl glycine, L-aspartic acid, L-glutamic acid, glycyl L-aspartic acid, glycyl L-glutamic acid, L-proline and $\alpha$-D-glucose 1-phosphate. All were negative for the following: assimilation of sucrose, mannitol, gluconate, caprate, adipate, phenyl acetate, $\alpha$-cyclodextrin, adonitol, L-arabinose, i-erythritol, myo-inositol, lactulose, raffinose, L-rhamnose, xylitol, cis-aconitic acid, citric acid, D-glucuronic acid, $\alpha$ hydroxybutyric acid, $\gamma$-hydroxybutyric acid, phenylethylamine, putrescine, 2-aminoethanol, 2,3-butanediol, glycerol, DL- $\alpha$-glycerol phosphate and D-glucose 6-phosphate. All three strains were sensitive to gentamicin, rifampicin, tetracycline, ampicillin, novobiocin, chloramphenicol, nalidixic acid and sulfamethoxazole plus trimethoprim. +, Positive; -, negative; R, resistant; $\mathrm{S}$, sensitive; ND, no data.

\begin{tabular}{|c|c|c|c|}
\hline Characteristic & $\begin{array}{c}\text { Strain } \\
\text { RIB1-20 }^{\mathrm{T}}\end{array}$ & $\begin{array}{l}\text { L. composti } \\
\text { CCUG } \\
53595^{\mathrm{T}}\end{array}$ & $\begin{array}{c}\text { L. mephitis } \\
\text { DSM } \\
12574^{\mathrm{T}}\end{array}$ \\
\hline Isolation source & Fresh water & Food waste & $\begin{array}{c}\text { Ammonia } \\
\text { biofilter }\end{array}$ \\
\hline $\begin{array}{l}\text { Reduction of nitrate to } \\
\text { nitrite }\end{array}$ & - & + & - \\
\hline \multicolumn{4}{|l|}{ Activity of (API ZYM): } \\
\hline Cystine arylamidase & + & - & - \\
\hline$\alpha$-Chymotrypsin & - & + & - \\
\hline$\alpha$-Glucosidase & + & + & - \\
\hline $\begin{array}{l}N \text {-Acetyl- } \beta \text {-glucos- } \\
\text { aminidase }\end{array}$ & + & + & - \\
\hline \multicolumn{4}{|c|}{ Assimilation of (API 20NE): } \\
\hline Glucose & + & + & - \\
\hline Arabinose & - & + & - \\
\hline Mannose & + & - & - \\
\hline Maltose & + & + & - \\
\hline Malate & + & - & - \\
\hline \multicolumn{4}{|c|}{ Oxidation of (Biolog GN2): } \\
\hline Dextrin & + & + & - \\
\hline D-Arabitol & - & + & + \\
\hline Cellobiose & - & + & + \\
\hline$\alpha$-D-Glucose & + & + & - \\
\hline Maltose & + & + & - \\
\hline D-Mannitol & - & + & + \\
\hline D-Mannose & + & - & - \\
\hline Trehalose & + & + & - \\
\hline Acetic acid & + & - & - \\
\hline Formic acid & + & - & - \\
\hline$\alpha$-Ketobutyric acid & + & - & - \\
\hline$\alpha$-Ketoglutaric acid & + & - & - \\
\hline$\alpha$-Ketovaleric acid & + & - & - \\
\hline Succinic acid & - & + & + \\
\hline L-Alanine & + & + & - \\
\hline L-Asparagine & - & + & + \\
\hline L-Histidine & - & + & - \\
\hline Inosine & + & - & - \\
\hline
\end{tabular}


Table 2. cont.

\begin{tabular}{|c|c|c|c|}
\hline Characteristic & $\begin{array}{c}\text { Strain } \\
\text { RIB1-20 }^{\mathrm{T}}\end{array}$ & $\begin{array}{l}\text { L. composti } \\
\text { CCUG } \\
53595^{\mathrm{T}}\end{array}$ & $\begin{array}{c}\text { L. mephitis } \\
\text { DSM } \\
12574^{\mathrm{T}}\end{array}$ \\
\hline \multicolumn{4}{|l|}{ Susceptibility to: } \\
\hline Kanamycin & $\mathrm{R}$ & s & $\mathrm{s}$ \\
\hline Penicillin G & $\mathrm{R}$ & s & s \\
\hline Streptomycin & $\mathrm{R}$ & s & $\mathrm{R}$ \\
\hline Ceftizoxime & S & $\mathrm{R}$ & $\mathrm{R}$ \\
\hline $\begin{array}{l}\text { DNA G }+ \text { C content } \\
(\mathrm{mol} \%)\end{array}$ & 70.3 & 68.1 & 67.0 \\
\hline
\end{tabular}

are not accumulated. After $24 \mathrm{~h}$ growth on R2A agar at $25{ }^{\circ} \mathrm{C}$, the mean cell size is about $0.5 \mu \mathrm{m}$ in width and $0.8-$ $1.0 \mu \mathrm{m}$ in length. Forms visible colonies that are round with umbonate elevation, smooth-edged and yellow-pigmented. Colonies are approximately $1.2-1.8 \mathrm{~mm}$ in diameter on R2A agar after $72 \mathrm{~h}$ incubation at $25{ }^{\circ} \mathrm{C}$. Grows at 15, 25, 30 and $37{ }^{\circ} \mathrm{C}, 0-3 \% \mathrm{NaCl}$ and $\mathrm{pH} 7-8$. Optimal growth occurs at $25{ }^{\circ} \mathrm{C}, 0 \% \mathrm{NaCl}$ and $\mathrm{pH}$ 7.0. Positive for the following: catalase (weak), cytochrome oxidase and hydrolysis of starch, casein and Tweens 20 (weak), 40 (weak), 60 (weak) and 80 (weak). Negative for DNase and lipase (corn oil) activities. Major fatty acids $(>20 \%)$ are iso- $C_{15: 0}$, iso- $C_{17: 0}$ and iso- $\mathrm{C}_{17: 1} \omega 9 \mathrm{c}$. The DNA G $+\mathrm{C}$ content of the type strain is $70.3 \mathrm{~mol} \%$. Additional phenotypic properties are shown in Table 2. The following compounds are utilized as sole carbon sources (in the Biolog GN2 test system): dextrin, glycogen, Tweens 40 and $80, N$-acetyl-D-galactosamine, $N$ acetyl-D-glucosamine, D-fructose, L-fucose, gentiobiose, $\alpha$ D-glucose, $\alpha$-D-lactose, maltose, D-mannose, methyl $\beta$-Dglucoside, D-psicose, D-sorbitol, sucrose, trehalose, turanose, pyruvic acid methyl ester, acetic acid, formic acid, Dgalactonic acid lactone, D-galacturonic acid, D-glucosaminic acid, $\beta$-hydroxybutyric acid, $p$-hydroxyphenylacetic acid, $\alpha$ ketobutyric acid, $\alpha$-ketoglutaric acid, $\alpha$-ketovaleric acid, DLlactic acid, malonic acid, propionic acid, sebacic acid, bromosuccinic acid, succinamic acid, L-alanine, L-alanyl glycine, L-aspartic acid, L-glutamic acid, glycyl L-aspartic acid, glycyl L-glutamic acid, hydroxy-L-proline, L-leucine, Lornithine, L-proline, L-serine, L-threonine, urocanic acid, inosine, uridine and $\alpha$-D-glucose 1-phosphate. Does not oxidize the remaining substrates of the Biolog GN2 test panel. Resistant to kanamycin, penicillin G and streptomycin, but sensitive to gentamicin, rifampicin, tetracycline, ampicillin, novobiocin, chloramphenicol, nalidixic acid and sulfamethoxazole plus trimethoprim.

The type strain, RIB1-20 ${ }^{\mathrm{T}}\left(=\mathrm{BCRC} 17731^{\mathrm{T}}=\mathrm{LMG} 24212^{\mathrm{T}}\right)$, was isolated from a freshwater sample from southern Taiwan.

\section{Acknowledgements}

W.-M. C. was supported by grants from the National Science Council, Taipei, Taiwan, Republic of China (NSC 95-2320-B-022-001-MY2 and 95-2313-B-022-001).

\section{References}

Chen, W. M., Laevens, S., Lee, T. M., Coenye, T., de Vos, P., Mergeay, M. \& Vandamme, P. (2001). Ralstonia taiwanensis sp. nov., isolated from root nodules of Mimosa species and sputum of a cystic fibrosis patient. Int J Syst Evol Microbiol 51, 1729-1735.

Chung, Y. C., Kobayashi, T., Kanai, H., Akiba, T. \& Kudo, T. (1995). Purification and properties of extracellular amylase from the hyperthermophilic archeon Thermococccus profundus DT5432. Appl Environ Microbiol 61, 1502-1506.

Ezaki, T., Hashimoto, Y. \& Yabuuchi, E. (1989). Fluorometric deoxyribonucleic acid-deoxyribonucleic acid hybridization in microdilution wells as an alternative to membrane filter hybridization in which radioisotopes are used to determine genetic relatedness among bacterial strains. Int J Syst Bacteriol 39, 224-229.

Finkmann, W., Altendorf, K., Stackebrandt, E. \& Lipski, A. (2000). Characterization of $\mathrm{N}_{2} \mathrm{O}$-producing Xanthomonas-like isolates from biofilters as Stenotrophomonas nitritireducens sp. nov., Luteimonas mephitis gen. nov., sp. nov. and Pseudoxanthomonas broegbernensis gen. nov., sp. nov. Int J Syst Evol Microbiol 50, 273-282.

Gerhardt, P., Murray, R. G. E., Wood, W. A. \& Krieg, N. R. (editors) (1994). Methods for General and Molecular Bacteriology. Washington, DC: American Society for Microbiology.

Hall, T. A. (1999). BioEdit: a user-friendly biological sequence alignment editor and analysis program for Windows 95/98/NT. Nucleic Acids Symp Ser 41, 95-98.

Kimura, M. (1983). The Neutral Theory of Molecular Evolution. Cambridge: Cambridge University Press.

Kluge, A. G. \& Farris, F. S. (1969). Quantitative phyletics and the evolution of anurans. Syst Zool 18, 1-32.

Kumar, S., Tamura, K. \& Nei, M. (2004). MEGA3: integrated software for molecular evolutionary genetics analysis and sequence alignment. Brief Bioinform 5, 150-163.

Lányí, B. (1987). Classical and rapid identification methods for medically important bacteria. Methods Microbiol 19, 1-67.

Lipski, A. \& Stackebrandt, E. (2005). Genus III. Luteimonas Finkmann, Altendorf, Stackebrandt and Lipski 2000, 280 VP. In Bergey's Manual of Systematic Bacteriology, 2nd edn, vol. 2, part B, pp. 93-94. Edited by D. J. Brenner, N. R. Krieg, J. T. Staley \& G. M. Garrity. New York: Springer.

MacFaddin, J. F. (2000). Biochemical Tests for the Identification of Medical Bacteria, 3rd edn. Baltimore, MD: Williams \& Wilkins.

Mesbah, M., Premachandran, U. \& Whitman, W. B. (1989). Precise measurement of the $\mathrm{G}+\mathrm{C}$ content of deoxyribonucleic acid by high-performance liquid chromatography. Int J Syst Bacteriol 39, 159-167.

Powers, E. M. (1995). Efficacy of the Ryu nonstaining KOH technique for rapidly determining gram reactions of food-borne and waterborne bacteria and yeasts. Appl Environ Microbiol 61, 3756-3758.

Saitou, N. \& Nei, M. (1987). The neighbor-joining method: a new method for constructing phylogenetic trees. Mol Biol Evol 4, 406-425.

Sasser, M. (1990). Identification of bacteria by gas chromatography of cellular fatty acids, MIDI Technical Note 101. Newark, DE: MIDI Inc.

Thompson, J. D., Gibson, T. J., Plewniak, F., Jeanmougin, F. \& Higgins, D. G. (1997). The CLUSTAL_X windows interface: flexible strategies for multiple sequence alignment aided by quality analysis tools. Nucleic Acids Res 25, 4876-4882. 
Wayne, L. G., Brenner, D. J., Colwell, R. R., Grimont, P. A. D., Kandler, O., Krichevsky, M. I., Moore, L. H., Moore, W. E. C., Murray, R. G. E. \& other authors (1987). International Committee on Systematic Bacteriology. Report of the ad hoc committee on reconciliation of approaches to bacterial systematics. Int J Syst Bacteriol 37, 463-464.
Young, C. C., Kämpfer, P., Chen, W. M., Yen, W. S., Arun, A. B., Lai, W. A., Shen, F. T., Rekha, P. D., Lin, K. Y. \& Chou, J. H. (2007). Luteimonas composti sp. nov., a moderately thermophilic bacterium isolated from food waste. Int J Syst Evol Microbiol 57, $741-744$. 